\title{
Carbon and oxygen isotope studies of graphite bearing carbonates in the Kasuga area, Gifu Prefecture, central Japan
}

\author{
HIDEKI WADA and SHINYA OANA \\ Department of Earth Sciences, Nagoya University, Chikusa, Nagoya, 464 Japan
}

(Received April 26, 1975; in revised form August 5, 1975)

\begin{abstract}
C} /{ }^{12} \mathrm{C}$ and ${ }^{18} \mathrm{O} /{ }^{16} \mathrm{O}$ ratios were determined for carbonate minerals and graphites in marbles from the contact metamorphic aureole in the Kasuga area, Gifu Prefecture, central Japan. ${ }^{13} \mathrm{C} /{ }^{12} \mathrm{C}$ ratios were determined also for carbonaceous materials in pelitic rocks.

${ }^{13} \mathrm{C} /{ }^{12} \mathrm{C}$ ratios of graphites in marbles approach the carbon isotopic range of coexisting carbonates, although they are considered according to their occurrence to be of biogenic origin. In a typical traverse of the carbonate aureole, carbon isotopic fractionation between calcite and coexisting graphite becomes regularly smaller toward the igneous contact. This strongly suggests that calcite and coexisting graphite approached isotopic equilibrium during contact metamorphism.

When we assume an isotopic equilibrium between calcite and graphite, we can estimate carbon isotopic temperatures, which reasonably agree with temperatures estimated from the solubility of magnesium in calcite coexisting with dolomite and from a heat flow model.

Carbon isotopic temperatures for the maximum contact temperature are estimated to be from 600 to $650^{\circ} \mathrm{C}$. The thermal gradient estimated from carbon isotopic ratios is gentle and agrees with that estimated from a heat flow model. Carbon isotopic temperature is considered to represent a temperature, which is closest to the maximum temperature during metamorphism.

Dolomite and coexisting calcite are considered to be in disequilibrium as to oxygen isotopes, although equilibrium between calcite and graphite is attained. This is probably due to the difference in resistivity between calcite and dolomite to oxygen isotopic exchange with hydrothermal water.
\end{abstract}

\section{INTRODUCTION}

Dispersed carbonaceous materials occur in sedimentary rocks and pelitic metamorphic rocks. Carbonaceous materials in highly metamorphosed rocks are changed to graphite forming scaly or fine-grained crystals. Progressive graphitization has been discussed in connection with the grade of metamorphism (QuINN and GLASS, 1958; FrenCH, 1964; Kato and NAKAI, 1966; GrifFIn, 1967; IzAWA, 1968; LANDIS, 1971). LANDIS (1971) studied especially the relationship between the structure of carbonaceous materials and metamorphic facies.

DEGENS (1969) summarized carbon isotopic studies from biogeochemical point of view. RanKama (1948a, b, 1954) and WiCKMAN and UBISCH (1951) suggested that graphites in Precambrian gneiss are classified by the carbon isotopic composition into two types, of organic and inorganic origins. CRAIG (1953, 1954), however, emphasized that it is impossible to identify the origin of a carbonaceous material by only its carbon isotopic ratios, because the isotopic composition may have shifted according to chemical and isotopic reactions.

HAHN-WEINHEIMER $(1960,1966)$ investigated carbon isotopic compositions of carbonate and graphite coexisting in metamorphic and igneous rocks, and showed that 
graphites could be classified in two groups, one is of organic origin and the other of inorganic. HAHN-WEINHEIMER et al. (1969) further showed a possibility that the heavy graphite from Kropfmühl in Bavaria, Germany was derived from ${ }^{13} \mathrm{C}$-rich carbonate by the Boudouard reaction $\left(2 \mathrm{CO}=\mathrm{CO}_{2}+\mathrm{C}\right)$.

BotTINGA (1969) calculated fractionation factors for carbon isotopic exchange equilibria between carbonaceous materials $\left(\mathrm{C}, \mathrm{CO}, \mathrm{CO}_{2}, \mathrm{CH}_{4}, \mathrm{CaCO}_{3}\right)$ over a wide temperature range from 0 to $700^{\circ} \mathrm{C}$. He estimated carbon isotopic temperatures for graphite-calcite pairs from Kropfmühl mentioned above, applying his fractionation factors between calcite and graphite. Many of these temperatures, however, are too high or too low as compared with inferred metamorphic temperatures (BotTinga, 1969). Shabo and Mamchur (1973) observed that the concentration of the light carbon in grpahite samples increased with increasing distance from limestone to gneiss. They also estimated equilibrium temperatures in the system of calcite and graphite. Some isotopic temperatures, however, are inconsistent with geological evidence. Carbonate-graphite pairs in these cases are considered not to have attained isotopic equilibrium.

Metamorphosed areas are formed under physico-chemical conditions, which are ruled by factors usually different in time and space. This may result in isotopic disequilibrium.

MiYamura (1967) and SuzuKi (1975) studied geologically the contact metamorphic aureole in Kasuga, Gifu Pref., central Japan and made clear that it was formed by a single metamorphism. The mineral and thermal zoning is simple and clear. Here we intend to demonstrate the feasibility of carbon isotopic temperature determinations in connection with geologic field evidence.

\section{SAmpling and Geological Setting}

The Kasuga area, Gifu Pref. is composed of limestone, dolomite, chert and green rocks of the Permian (Fig. 1) (Miyamura, 1967; Suzuki, 1975). Carbonate rocks form lenticular beds concordant with other formations. These sedimentary rocks were subjected to a contact metamorphism by a granite body in the north of this district. An absolute age determination with the K-Ar method (73m.y) (KONO and UEDA, 1966) showed that the granite was intruded in the upper Cretaceous. The metamorphic aureole extends about $2 \mathrm{~km}$ outward perpendicular to the granite contact, and limestone and dolomite change to marble and other rocks to hornfels and/or crystalline schist.

High amphibolite facies near the

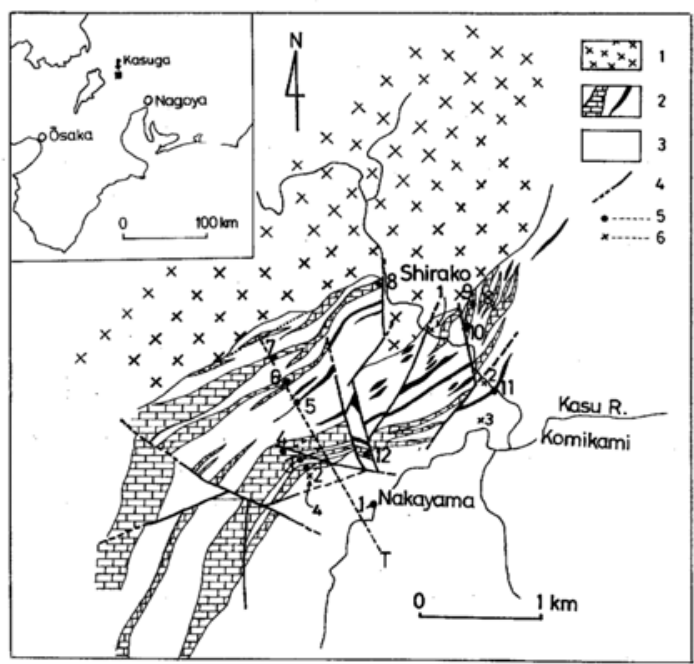
granite contact changes to green-schist facies about 1 to $1.5 \mathrm{~km}$ outward from the contact (SuzuKI, 1975).

The strike of the contact surface seems to be nearly parallel to that of sedimentary rocks. The isograds of this area, therefore, are parallel to the strike of the formations (SUZUKI, 1975).

Fig. 1. Index map of the Kasuga area, Gifu Pref., showing the distribution of a granite intrusive, marble and sample locality. Legend; 1: granite intrusive rocks. 2: limestone and dolomite. 3: green rocks, chert, shale, slate and sandstone. 4: fault. 5: sampling points of limestone and dolomite. 6: sampling points of pelitic rocks. (gelology after SUZUKI, 1975) 
Considerable amounts of wollastonite are formed near the contact between limestone marble and granite. Skarn minerals such as diopside, forsterite and garnet are found near the contact between dolomite marble and granite. Many quartz veins stretch out from the granite body, filling fissures in sedimentary rocks. Zones of chemical reactions between quartz and minerals in sedimentary rocks are several centimeters wide.

In order to investigate the relationship between the contact metamorphic grade and the carbon isotopic composition, we collected samples successively along lines perpendicular to the contact.

A valley in the west of Nakayama runs perpendicular to the contact and cuts six limestone beds. Successive outcrops are located along Kasu river in the north of Komikami. Some faults, however, are found along the river, making it difficult to estimate exactly the distance from the contact to each outcrop.

Samples nearest the granite contact were collected in a tunnel of the Shirako dolomite mine. Pure calcite marble consists of rather large grains of a few millimeters and is black or dark gray in color. Dolomite marble consists of small grains, contains at least $10 \%$ of calcite, and is light gray or gray in color, containing carbonaceous material less than does pure calcite. These evidences contradict the inhibiting effect of organic substances on the crystallization of limestone (RoBINSON, 1971), but do not conflict with the fact that dolomite is more resistant to alteration than is calcite (EPSTEIN et al., 1964).

\section{EXPERIMENTAL}

Carbon isotopic ratios in carbonate samples were determined for $\mathrm{CO}_{2}$ liberated from them with $100 \% \mathrm{H}_{3} \mathrm{PO}_{4}$ at $25^{\circ} \mathrm{C}$ in vacuum (MCCREA, 1950). For the separate collection of $\mathrm{CO}_{2}$ from calcite and dolomite a chemical technique developed by EPSTEIN et al. (1964) was slightly modified (Suwa et al., 1969) and used.

Carbonate-free material is collected as follows: About $100 \mathrm{~g}$ of a powdered sample is treated with hydrochloric acid $(1: 1)$ on a water bath, then treated with a mixture of concentrated hydrofluoric and hydrochloric acids on a water bath to decompose silicate minerals. The residual matter is composed almost of carbonate-free carbonaceous matter. Several milligrams of carbonaceous matter is put into a quartz vessel, and is burnt to $\mathrm{CO}_{2}$ in pure oxygen at $900^{\circ} \mathrm{C}$. When the sample contains some amounts of sulfide minerals, evolved $\mathrm{SO}_{2}$ is removed from $\mathrm{CO}_{2}$ at the melting point of $n$-pentane (MIZUTANI and OANA, 1973). Carbon dioxide thus purified is used for mass spectrometric determinations.

The mass spectrometer used is a double collector Nier-McKinney type instrument, Varian Mat $\mathrm{CH} 7$.

The isotopic composition of a sample is reported in $\delta$-notation,

$$
\delta(\%)=\left(\frac{R_{\text {sample }}}{R_{\text {standard }}}-1\right) \times 1,000
$$

where $R$ is ${ }^{13} \mathrm{C} /{ }^{12} \mathrm{C}$ or ${ }^{18} \mathrm{O} /{ }^{16} \mathrm{O}$ ratio in sample or standard. The standards are PDB (CRAIG, 1957) for carbon and SMOW (CRAIG, 1961) for oxygen. A working standard is used in practice. Its isotopic ratios are determined with respect to the NBS-Solenhofen standard (CraIG, 1957).

The fractionation factor, $\alpha_{A-B}$, between two substances $A$ and $B$ is defined as

$$
\alpha_{\mathrm{A}-\mathrm{B}}=\frac{R_{\mathrm{A}}}{R_{\mathrm{B}}}
$$

where $R$ is ${ }^{13} \mathrm{C} /{ }^{12} \mathrm{C}$ or ${ }^{18} \mathrm{O} /{ }^{16} \mathrm{O}$ in $\mathrm{A}$ and $\mathrm{B}$.

When $\alpha$ is very close to unity, 1,000 $\ln \alpha_{\mathrm{A}-\mathrm{B}}=\delta_{\mathrm{A}}-\delta_{\mathrm{B}} .1,000 \ln \alpha_{\mathrm{A}-\mathrm{B}}$ is denoted 
by $\Delta_{\mathrm{A}-\mathrm{B}}$ in this paper.

Carbonate minerals, graphite and other carbonaceous materials are identified by the X-ray powder method.

\section{Discussion}

Carbon and oxygen isotopic compositions of carbonates

Carbonate samples are composed of dolomite and calcite except for 73080406A,B and 73080407, which are nearest the granite contact, and $\mathrm{Ka}-02$, which is farthest from the contact.

The dolomite component is more abundant in almost all samples than the calcite component.

The isotopic ratios of calcite and dolomite from the Kasuga area are listed in Table 1.

Table 1. $\delta^{13} \mathrm{C}$ and $\delta^{18} \mathrm{O}$ of carbonates and coexisting graphites.

\begin{tabular}{|c|c|c|c|c|c|c|c|}
\hline Sample No. & $\begin{array}{l}\text { Distance } \\
\text { from the } \\
\text { contact } \\
(\mathrm{m})\end{array}$ & $\begin{array}{l}\text { Calcite } \\
\text { dolomite } \\
\text { ratio }\end{array}$ & $\begin{array}{r}\delta^{13} \mathrm{C} \\
\text { Calc }\end{array}$ & $\delta_{\text {part }}^{18} \mathrm{O}$ & $\begin{array}{c}\delta^{13} \mathrm{C} \\
\text { Dolo }\end{array}$ & $\delta^{18} \mathrm{O}$ & $\begin{array}{l}\quad \delta^{13} \mathrm{C} \\
\quad(\% 0) \\
\text { Graphite or } \\
\text { carbonaceous } \\
\text { material }\end{array}$ \\
\hline \multicolumn{8}{|l|}{ Nakayama traverse } \\
\hline 1. 73080408 & 1,680 & $20: 100$ & +3.9 & +25.2 & +5.0 & +28.4 & -5.6 \\
\hline 2. 73050503 & 1,150 & $8: 100$ & +3.5 & +24.0 & +4.0 & +28.1 & -5.4 \\
\hline 3. 73050504 & 1,060 & $100: 30$ & +4.1 & +26.4 & +4.7 & +28.5 & -4.4 \\
\hline 4. 73050505 & 960 & $50: 50$ & +4.3 & +24.6 & +5.2 & +27.3 & -4.4 \\
\hline 5. 73080401 & 610 & $100:<5$ & +3.5 & +26.0 & +4.2 & +27.4 & -4.6 \\
\hline \multirow{2}{*}{$\begin{array}{l}73080405 \mathrm{~A} \\
73080405 \mathrm{~B}\end{array}$} & 410 & $12: 100$ & +0.5 & +21.9 & +1.3 & +25.3 & -5.9 \\
\hline & 410 & $17: 100$ & +2.2 & +23.1 & +3.9 & +25.8 & -3.6 \\
\hline \multirow{3}{*}{ 7. $\begin{array}{r}730 \\
730 \\
730\end{array}$} & 190 & $100: 0$ & +3.8 & +26.9 & & & -2.1 \\
\hline & 190 & $100: 0$ & +4.2 & +29.0 & & & -1.6 \\
\hline & 190 & $100: 0$ & +3.3 & +26.6 & & & -2.9 \\
\hline \multicolumn{8}{|l|}{ Others } \\
\hline 8. $72082301 \mathrm{~B}$ & 100 & $14: 100$ & +3.0 & +23.0 & +2.9 & +25.0 & -3.4 \\
\hline 9. $72082305 \mathrm{~A}$ & $<50$ & $11: 100$ & +4.2 & +24.2 & +4.8 & +27.4 & -1.8 \\
\hline 10. $72082305 \mathrm{C}$ & $<50$ & $10: 100$ & +2.5 & +17.6 & +4.8 & +30.4 & -4.7 \\
\hline 11. 72082309 & 600 & $11: 100$ & +0.8 & +22.0 & +2.0 & +25.1 & -8.6 \\
\hline 12. $72082311 \mathrm{~B}$ & 700 & $9: 100$ & +2.1 & +17.0 & +4.1 & +26.5 & -4.9 \\
\hline 13. $\mathrm{Ka}-02$ & $>2,000$ & $100: 0$ & +4.1 & +26.8 & & & -25.0 \\
\hline
\end{tabular}

$\delta^{13} \mathrm{C}$ and $\delta^{18} \mathrm{O}$ of the dolomite component are distributed from +1.3 to $+5.2 \%$ with respect to $\mathrm{PDB}$, and from +25.1 to $+30.4 \%$ with respect to SMOW, respectively. The extent of these variations is usual in marble (SHIEH and TAYLOR, 1970).

OSAKI (1973) reported carbon and oxygen isotopic compositions of dolomite from Miyama, Gifu Pref., where Permian dolostone and limestone are distributed. These Permian formations have not been subjected to any thermal metamorphism, and are correlated with the marble in the Kasuga area. Carbon and oxygen isotopic ratios for the dolomite component is similar for Kasuga and Miyama samples. Therefore, the isotopic composition of dolomite in the Kasuga area is considered not to have changed since dolomite was formed, though it was subjected to a thermal metamorphism.

$\delta^{13} \mathrm{C}$ and $\delta^{18} \mathrm{O}$ values of calcite from calcite marble (deficient in dolomite component) fall in the relatively narrow ranges from +3.3 to $+4.2 \%$, and from +26.6 to $+29.0 \%$, respectively, which are similar to the ranges of $\delta$ values for dolomites. This suggests that the calcite marble did not appreciably change carbon and oxygen isotopic compositions since it was formed.

The isotopic ratios of calcite coexisting with dolomite, however, are from +0.5 to 
$+4.3 \%$ for carbon and from +17.0 to $+26.0 \%$ for oxygen. They are distributed in wide ranges compared with $\delta$ values of coexisting dolomite.

Carbon and oxygen isotopic compositions of dolomite are heavier than those of coexisting calcite, when both minerals are in isotopic equilibrium (ScHWARCZ, 1966). SHEPPARD and ScHWARCZ (1970) showed that $\Delta^{13} \mathrm{C}_{\mathrm{Do}-\mathrm{Cc}}$ and $\Delta^{18} \mathrm{O}_{\mathrm{Do}-\mathrm{Cc}}$ for contact metamorphosed coexisting dolomite and calcite fall on a regression curve.

$\Delta^{13} \mathrm{C}_{\mathrm{Do}-\mathrm{C} c}$ and $\Delta^{18} \mathrm{O}_{\mathrm{Do}-\mathrm{C}}$ values for Kasuga samples are plotted in Fig. 2. They do not fall on the regression curve by SHEPPARD and Schwarcz (1970) and seem to form a different regression curve.

According to these facts and oxygen fractionation factor between dolomite and calcite (EPSTEIN et al., 1964; SchwarCZ, 1966; O’Neil and EPSTEIN, 1966; ShePPARD and SCHWARCZ, 1970), dolomite and coexisting calcite in the Kasuga area are not considered to be in isotopic equilibrium (Fig. 3).

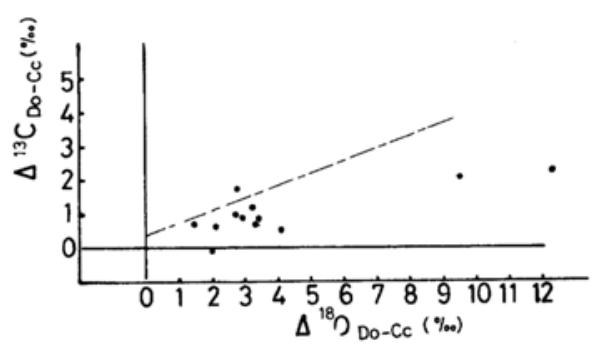

Fig. 2. $\Delta^{13} C_{\text {dolomite-calcite }}$ v. $\Delta^{18} O_{\text {dolomite-calcite }}$ for dolomite-calcite pairs from the Kasuga area. Diagonal dashed line is derived from regional metamorphic marble (SHEPPARD and SCHWARCZ, 1970)

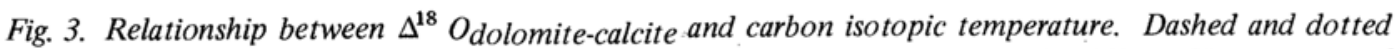
lines are oxygen isotopic fractionation curves obtained by O'NEIL and EPSTEIN (1966) and NORTHROP and CLAYTON (1966), respectively.

When these carbonate rocks were metamorphosed, only oxygen in calcite might have exchanged with connate water or meteoric water, because calcite is less resistible in isotopic exchange than dolomite (EPSTEIN et al., 1964).

Carbon isotopic ratios of carbonaceous materials in marble and pelitic rocks Carbon isotopic ratios of dispersed carbonaceous materials in marble and pelitic rocks are listed in Tables 1 and 2, respectively.

Dispersed carbonaceous materials in marbles from the Kasuga area were confirmed by the X-ray diffraction method to be finely crystalline graphites. None of scaly graphite, such as Kropfmühl graphite (HAHN-WeINHEIMER, 1966) and Kamioka graphite (NOZAWA, 1952), are found in the Kasuga area. Thus these graphites from the Kasuga area are considered according to their occurrence to be of biogenic origin.

Carbonaceous material in the non-metamorphosed limestone, Ka-02 has a low $\delta^{13} \mathrm{C}$ value, suggesting its biogenic origin. $\delta^{13} \mathrm{C}$ values of graphites in marbles, -8.6 to $-1.6 \%$ o are considerably heavier than those of typical biogenic carbon. Nevertheless these graphites are considered to be of biogenic origin as mentioned above.

HAHN-W EINHEIMER (1966) and HAHN-WeINHEIMER et al. (1969) reported that graphites 
Table 2. $\delta^{13} \mathrm{C}$ of carbon and carbon contents of pelitic rocks

\begin{tabular}{lcccc}
\hline Sample No. & Rock & $\begin{array}{c}\text { Distance from } \\
\text { the contact } \\
(\mathrm{m})\end{array}$ & $\begin{array}{c}\text { Carbon } \\
\text { wt. } \%\end{array}$ & $\begin{array}{l}\delta^{13} \mathrm{C} \\
(\%)\end{array}$ \\
\hline 1. $72082304 \mathrm{~A}$ & black schist & 50 & 1.3 & -25.2 \\
2. 72082307 & shale & 500 & 1.3 & -28.4 \\
3. 72082307 & slate & 850 & 0.8 & -22.6 \\
4. 73050502 & shale & 1,200 & 2 & -26.6 \\
\hline
\end{tabular}

in marble could be recognized in two groups, one group was of biogenic origin and the other of non-biogenic. Non-biogenic graphite occurs in marble as scales and is enriched in ${ }^{13} \mathrm{C}$. $\delta^{13} \mathrm{C}$ in slates or shales are -22.6 to $-28.4 \%$ and fall in a relatively narrow range. The carbon isotopic ratios in Paleozoic and younger marine shales or slates have values lighter than $-25 \%$ o (CRAIG, 1953, 1954). A sample, 72082310 occurs in slate $850 \mathrm{~m}$ from the contact and its $\delta^{13} \mathrm{C}$ is slightly heavy. The carbon content of this sample is also slightly low compared with the other samples (see Table 2). This low carbon content may have been derived by consumption of carbonaceous material as an oxygen buffer during metamorphism. If any difference results in the $\delta^{13} \mathrm{C}$ value, it's in the direction of making the remnant heavy.

Nakayama traverse Nakayama traverse is shown in Fig. 1 by a dashed line designated T. Several outcrops of marble are exposed along this traverse. The carbon isotopic ratios of calcites and coexisting graphites in marbles are plotted with respect to the distance from the igneous contact in Fig. 4. Figure 5 shows the relationship between $\Delta^{13} \mathrm{C}_{\mathrm{Cc}} \mathrm{Gr}$ in marbles and the distance from the contact in the same traverse. In Figs. 4 and 5 and in Table 1, we can recognize a decrease in $\Delta^{13} \mathrm{C}_{\mathrm{C}}-\mathrm{Gr}$ toward the igneous contact. Carbon isotopic composition of calcite is almost constant regardless of the distance from the contact, whereas the carbon of graphites coexisting with carbonates becomes evidently heavier toward the igneous contact. These graphites are considered to have been derived from organic materials, $\delta^{13} \mathrm{C}$ values of which were originally from -25 to $-30 \%$. Organic materials in the limestone have been converted into graphite, their carbon isotopic composition becoming progressively heavier during the contact metamorphism.

Enrichment of ${ }^{13} \mathrm{C}$ in carbonaceous materials in marble may have been performed by either of the following mechanisms:

1) Thermal cracking of organic matter to form graphite,

2) Reaction with gases equilibrated with graphite, or

3) Isotopic exchange between calcite and graphite.

SACKET et al. (1966) studied thermal cracking of oil and showed that carbon isotopic fractionation between methane formed by cracking and residual organic carbon depends on the physical characters of carbon-carbon bonds in organic compounds. Numerical estimation of the carbon isotopic fractionation for the present study, however, is difficult, because original structures of organic compounds involved are unknown. This mechanism may also be considered in slate and shale. Graphites in slate or shale are not deviated in the carbon isotopic composition from organic carbon. This may suggest that they are biogenic in origin and have not changed their carbon isotopic compositions through metamorphism. This is also shown for graphites in Precambrian gneiss (ANDREAE, 1974).

Effects of the 2nd mechanism will be expected, especially when gaseous fluid from a granite body flows into sedimentary rocks and forms skarn minerals. Therefore, we assume chemical equilibrium between graphite and water, and estimate carbon isotopic fractionations between them according to BotTINGA (1969). Dissociation pressure of calcite under $600^{\circ} \mathrm{C}$ is so small that we can neglect the contribution of calcite to gas components (WILLIE and TuTtLE, 1960).

FRENCH (1966) theoretically calculated mutual ratios of the amounts of carbon 
dioxide and methane under various total pressures and temperatures in the stability field for graphite. The partial pressures of both gases are nearly equal at $600^{\circ} \mathrm{C}$. According to BotTinga (1969) the fractionation factor between carbon dioxide and graphite $\Delta \mathrm{CO}_{2}-\mathrm{C}$ (graphite) is smaller than that between graphite and methane $\Delta \mathrm{C}$ (graphite) $-\mathrm{CH}_{4}$ at temperatures lower than $280^{\circ} \mathrm{C}$. At temperatures higher than $280^{\circ} \mathrm{C}$, however, this relationship becomes reverse, and the $\delta^{13} \mathrm{C}$ value of the gaseous phase should be greater than that of graphite.

The metamorphic temperature in the Kasuga area is supposed on mineralogical and geological evidence to have been higher than $400^{\circ} \mathrm{C}$. When the gases equilibrated with graphite at this temperature were removed, the $\delta^{13} \mathrm{C}$ value of remaining graphite could not increase to the observed values.

The 3rd mechanism seems to be natural and should be most effective, if realized. Since marble in the Kasuga area contains only small amounts of graphite, isotopic exchange between them would not significantly affect the carbon isotopic composition of marble, and should strongly control $\delta^{13} \mathrm{C}$ of graphite (see Fig. 4). BoTTINGA (1969) calculated fractionation factors between calcite and graphite in a temperature range from 0 to $700^{\circ} \mathrm{C}$. Applying these values, we can estimate carbon isotopic temperatures as shown in Table 3 . Along the Nakayama traverse, the relationship between the carbon isotopic temperature and the distance of sampling sites from the contact is shown in Fig. 6. The distances from the contact are estimated on a geological map.

Table 3. Carbon isotopic temperature and magnesium solvus temperature

\begin{tabular}{cccc}
\hline Sample No. & $\Delta^{13} \mathrm{C}_{\mathrm{Cc}-\mathrm{Gr}}(\%)$ & $\begin{array}{c}\text { Carbon isotopic } \\
\text { temperature } \\
\left({ }^{\circ} \mathrm{C}\right)\end{array}$ & $\begin{array}{c}\text { Magnesium } \\
\text { solvus } \\
\text { temperature } \\
\left({ }^{\circ} \mathrm{C}\right)\end{array}$ \\
\hline Nakayama traverse & +9.5 & 365 & $<400$ \\
1. 73080408 & +8.9 & 390 & $<400$ \\
2. 73050503 & +8.5 & 430 & $<400$ \\
3. 73050504 & +8.7 & 410 & $<400$ \\
4. 73050505 & +8.1 & 450 & - \\
5. 73080401 & +6.4 & 580 & 580 \\
6. 73080405A & +5.8 & 650 & - \\
$73080405 \mathrm{~B}$ & +5.9 & 640 & - \\
7. 73080406A & +5.8 & 650 & \\
$73080406 \mathrm{~B}$ & +6.2 & 600 & 580,570 \\
73080407 & & & 570 \\
Others & +6.4 & 580 & - \\
8. 72082301B & +6.0 & 630 & 440 \\
9. 72082305A & +7.3 & 500 & 510 \\
10. 72082305C & +9.3 & 370 & $<400$ \\
11. 72082309 & +7.0 & 530 & $<0$ \\
12. 72082311B & +29.0 & & $<0$ \\
13. Ka-02 & & &
\end{tabular}

Comparison with solvus temperature

Goldsmith et al. (1961) and Goldsmith and NEwTON (1969) studied magnesium content of magnesian calcite coexisting with dolomite and estimated solvus temperatures by magnesium content of calcite. SuzUKI (1975) analyzed magnesium in calcite coexisting with dolomite by the X-ray diffraction method and estimated solvus temperatures for some samples which were collected from the same sites as in this work. Solvus temperatures are listed in Table 3 in comparison with carbon isotopic temperatures. They agree with each other fairly well. The average isotopic temperature near the contact is about $620^{\circ} \mathrm{C}$, which is consistent with the geological fact that the highest metamorphic facies near the contact is high amphibolite (SUzUKI, 1975). Figure 7 shows the relationship between the carbon isotopic temperatures and other mineralogical evidences in the Kasuga area investigated by SuzUKI (1975). On phase equi- 

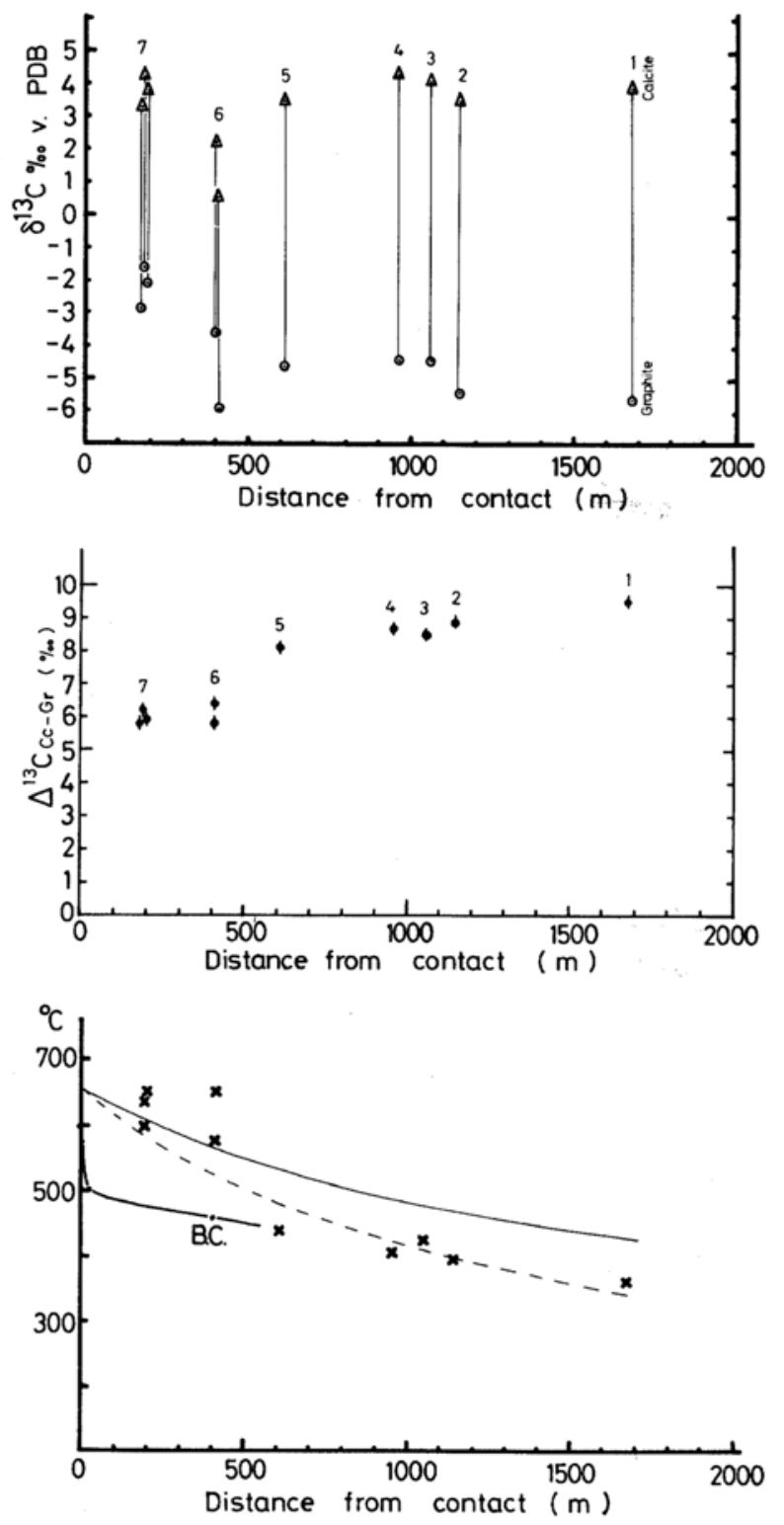

Fig. 4. ${ }^{13} \mathrm{C} /{ }^{12} \mathrm{C}$ ratios of calcite and coexisting graphite $v$. distance of sampling sites from the igneous contact along the Nakayama traverse. Numbers correspond to those in Fig. 1 .

Fig. 5. $\quad \Delta^{13} C_{\text {calcite-graphite values }}$ along the Nakayama traverse with respect to the distance from the igneous contact. Numbers correspond to those in Fig. 1.

Fig. 6. Relationship between carbon isotopic temperature and distance of sampling sites from the contact along the Nakayama traverse. The solid and dotted curvers are maximum temperature curves (JEAGER, 1959). The solid curve is for the case of equal thermal properties of country rock and magma and of latent heat of $80 \mathrm{cal} / \mathrm{g}$. The dotted curve is for the case of no latent heat and thermal properties of shale and granite porphyry. The solid curve, B.C., is oxygen isotopic temperature gradient for the Birch Creek traverse given by SHIEH and TAYLOR (1969b).

libria in metamorphosed siliceous marbles, METZ and TrommsDorfF (1968) showed stability fields for talc and tremolite by experiment and calculation. When the total pressure is 1,000 bars, talc can be formed at temperatures between 400 and $500^{\circ} \mathrm{C}$ and tremolite above $500^{\circ} \mathrm{C}$ (SUZUKI, 1975). In Fig. 7 the distributions of tremolite and talc are consistent with carbon isotopic temperatures except for two samples, Nos. 5 and $12\left(450\right.$ and $530^{\circ} \mathrm{C}$, respectively).

Comparison with a heat flow model JEAGER (1959) calculated the temperature gradient in the vicinity of a contact between an intrusive and a country rock. We calculate a maximum temperature curve for the Nakayama traverse on a heat flow model of JEAGER. The dimension of the granite intrusion in the Kasuga area is about $5,000 \mathrm{~m}$ in NW-SE and a little larger than $5,000 \mathrm{~m}$ in NE-SW (SuzuKI, pers. com.). Assuming that the contact temperature is $650^{\circ} \mathrm{C}$ and the latent heat is $80 \mathrm{cal} / \mathrm{g}$ or zero, we get maximum temperature 


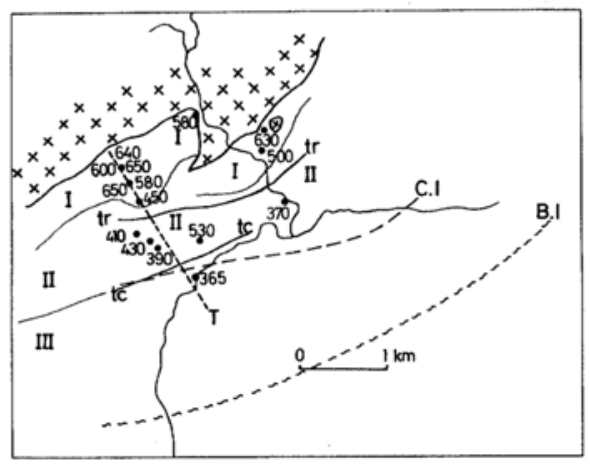

Fig. 7. Carbon isotopic temperatures and mineral parageneses in the Kasuga area. Abbreviations are as follows; tr: tremolite isograd, tc: talc isograd, C.I: cordierite isograd, B.I: biotite isograd. Zone I: brown hornblende zone, Zone II: blue green hornblende zone, Zone III: actinolite zone, figures: carbon isotopic temperature. (mineral parageneses after SUZUKI, 1975).

curves in Fig. 6. We cannot estimate strictly the distance from the igneous contact, because of the irregular shape of the granite body. Therefore, the relationship between carbon isotopic temperatures and the apparent distance from the contact cannot be strictly compared with these theoretical curves. Estimated isotopic temperatures seem to decrease at places farther than $500 \mathrm{~m}$ from the contact along a heat flow model without latent heat. We, however, do not intend to discuss the latent heat of the granite intrusive with those limited data.

SHIEH and TAYLOR (1969b) studied oxygen isotopic temperatures of contact metamorphism, and obtained an average contact temperature of $580^{\circ} \mathrm{C}$ from oxygen isotopic fractionations between two silicate minerals in the Birch Creek traverse. The solid line B.C. in Fig. 6 represents the oxygen isotopic temperature curve in the Birch Creek (SHIEH and TAYLOR, 1969b). Carbon isotopic temperatures farther than $500 \mathrm{~m}$ from the contact fall on the extrapolation of the Birch Creek isotopic temperature gradient. This gentle decrease in temperature might have been realized by a large granite body as in the case of the Birch Creek traverse. High temperatures as far as $400 \mathrm{~m}$ from the main contact might have resulted from a small intrusive, which is located $400 \mathrm{~m}$ from the main contact on the Nakayama traverse.

Oxygen fugacity in metamorphic aureole is maintained low, as long as graphite exists (MiYashiro, 1964). Graphite cannot be found and oxygen fugacity should be high in marble near quartz veins, where quartz reacts with calcite and/or dolomite to form wollastonite and/or diopside and forsterite etc. Aqueous fluid containing silica is considered to have intruded into fissures of carbonate rocks in such locations, and graphite or organic carbon might have disappeared. Carbonate rocks in the Kasuga area contain only small amount of organic carbon even where they were not subjected to metamorphism. Therefore, marble with a small amount of graphite implies that it was scarcely affected by aqueous fluid during metamorphism in the Kasuga area. When isotopic equilibrium between calcite and graphite is once attained in marble, isotopic compositions of calcite and graphite are retained during the subsequent lowering of metamorphic temperature, because of the lack of aqueous fluid and the high stability of crystalline graphite. The carbon isotopic temperature is thus considered to represent the maximum temperature in the metamorphism.

\section{CONCLUSIONS}

1) Graphite in the Kasuga marble is finely crystalline and is considered to be of organic origin from its occurrence.

2) Carbon isotopic fractionation between calcite and graphite progressively decreases with increasing distance from the igneous contact along the Nakayama traverse.

3) When we assume carbon isotopic equilibrium between calcite and coexisting 
graphite in marble, carbon isotopic temperatures reasonably agree with solvus temperatures of magnesian calcites, heat flow temperatures and mineral paragenesis.

4) Maximum contact temperature is estimated to be from 600 to $650^{\circ} \mathrm{C}$, according to the carbon isotopic fractionations. Carbon isotopic maximum temperature represents the maximum metamorphic temperature.

5) ${ }^{18} \mathrm{O}$ depletion for some calcites coexisting with dolomite in the Kasuga marble results from the oxygen isotopic exchange with connate or meteoric water, since calcite constitutes small fractions of the marble and is more susceptible to isotopic exchange than dolomite.

6) Carbon in pelitic rocks of contact metamorphic aureole is of organic origin. Its isotopic composition is typically organic, and varies at most several per mills during contact metamorphism.

\section{ACKNOWLEDGMENTS}

We wish to express our gratitudes to Associate Professor N. NAKAI of Nagoya University for stimulating and helpful discussion. We are also grateful to Mr. K. SUZUKI of Nagoya University for geological advice and providing data of solvus temperatures. Thanks are due to Dr. S. OSAKI of Kyushu University, who gave us instructive advice for experimental techniques.

\section{REFERENCES}

ANDREAE, M. O. (1974) Chemical and stable isotope composition of the high grade metamorphic rocks from the Arendal area, Southern Norway. Contr. Mineral. Petrol. 47, 299-316.

BotTINGA, Y. (1969) Calculated fractionation factors for carbon and hydrogen isotope exchange in system calcite-carbon dioxide-graphite-methane-hydrogen-water vapor. Geochim. Cosmochim. Acta 33, 49-64.

CraIG, H. (1953) The geochemistry of stable carbon isotopes. ibid. 3, 53-92.

CraIG, H. (1954) Geochemical implications of the isotope composition of carbon in ancient rocks. ibid. 6, 186-196.

CRAIG, H. (1957) Isotope standards for carbon and oxygen and correction factors for mass-spectrometric analysis of carbon dioxide. ibid. 12, 133-149.

CRAIG, H. (1961) Standard for reporting concentrations of deuterium and oxygen-18 in natural waters. Science 133, 1833-1834.

DEGENS, E. T. (1969) Biogeochemistry of stable carbon isotopes. Organic geochemistry, ed. G. EGLINTON and M. T. J. MURPHY, Springer-Verlag, Berlin-Heidelberg-New York, 304-349.

EPSTEIN, S., GRAF, D. L. and DEGENS, E. T. (1964) Oxygen isotope studies on the origin of dolomites. Isotopic and cosmic chemistry, ed. H. CRAIG et al., North-Holland, Amsterdam,169-180.

FRENCH, B. M. (1964) Graphitization of organic material in a progressively metamorphosed Precambrian iron formation. Science 146, 917-918.

FRENCH, B. M. (1966) Some geological implications of equilibrium between graphite and a C-H-O gas phpse at high temperatures and pressures. Rev. Geophys. 4, 223-253.

GoldSMITH, J. R., GRAF, D. L. and HEARD, H. C. (1961) Lattice constants of the calcium-magnesium carbonates. Am. Min. 46, 453-457.

Goldsmith, J. R. and Newton, R. C. (1969) P-T-X relations in the system $\mathrm{CaCO}_{3}-\mathrm{MgCO}_{3}$ at high temperatures and pressures. Am. J. Sci. 267-A, 160-190.

GriffiN, G. M. (1967) X-ray diffraction techniques applicable to studies of diagenesis and low rank metamorphism in humic sediments. J. Sediment. Petrol. 27, 1006-1011.

HAHN-WEINHEIMER, P. (1960) Alterseinstufung von eklogitischen Gesteinen mit Hilfe des $\mathrm{C}^{12} / \mathrm{C}^{13}$. Isotopenverhältnisses von Graphit-und Karbonat-Kohlenstoff. Geol. Rundsch. 49, 308-314.

HAHN-WEINHEIMER, P. (1966) Die isotopische Verteilung von Kohlenstoff und Schwefel in Marmor und anderen Metamorphiten. ibid. 55, 197-209.

HAHN-WEINHEIMER, P., MARKL, G. and RASCHKA, H. (1969) Stable carbon isotope compositions of 
graphite and marble in the deposit of Kropfmühl/NE bavaria. Advances in organic geochemistry, Pergamon Press.

IZAWA, E. (1968) Carbonaceous matter in some metamorphic rocks in Japan. J. Geol. Soc. Jap. 74, $427-432$.

JEAGER, J. C. (1959) Temperatures outside a cooling intrusive sheet. Am. J. Sci. 257, 44-54.

KATO, K. and NAKAI, N. (1966) Carbon in Metamorphic rocks (abs.). Geochem. Soc. Jap. Annual Meeting, 78-79.

Kono, Y. and UEDA, Y. (1966) K-A dating on the igneous rocks in Japan (V). J. Jap. Assoc. Min. Petrol. Econ. Geol. 56, 191-211 (in Japanese with English abstract).

LANDIS, C. A. (1971) Graphitization of dispersed carbonaceous material in metamorphic rocks. Contr. Mineral. Petrol. 30, 34-45.

MCCREA, J. M. (1950) On the isotopic chemistry of carbonates and a paleotemperature scale. $J$. Chem. Phys. 18, 849-857.

METZ, P. and TROMMSDORFF, V. (1968) On phase equilibria in metamorphosed siliceous dolomites. Contr. Mineral. Petrol. 18, 305-309.

MiYamuRA, M. (1967) Stratigraphy and geological structure of the Permian formations of Mt. Ibuki and its vicinity, Central Japan. Rept. No. 224, Geol. Surv. Japan.

MiYASHIRO, A. (1964) Oxidation and reduction in the earth's crust with special reference to the role of graphite. Geochim. Cosmochim. Acta 28, 717-729.

MiZUTANI, Y. and OANA, S. (1973) Separation of $\mathrm{CO}_{2}$ from $\mathrm{SO}_{2}$ with frozen $n$-pentane as a technique for the precision analysis of ${ }^{18} \mathrm{O}$ in sulfates. Mass Spectroscopy Japan 21, 255-258.

Northrop, D. A. and Clayton, R. N. (1966) Oxygen isotope fractionations in systems containing dolomite. J. Geol. 74, 174-196.

Nozawa, T. (1952) On the forming of graphite deposites in Hida Plateau. J. Geol. Soc. Japan 3, 305311 (in Japanese with English abstract).

O'NEIL, J. R. and EPSTEIN, S. (1966) Oxygen isotope fractionation in the system dolomite-calcitecarbon dioxide. Science 152, 198-201.

OSAKI, S. (1973) Carbon and oxygen isotopic compositions of Tertiary and Permian dolomites in Japan. Geochem. J. 6, 163-177.

QUINN, A. W. and Glass, H. D. (1958) Rank of coal and metamorphic grade of rocks of the Narragansett Basin of Rhode Island. Econ. Geol. 53, 563-576.

RANKAMA, K. (1948a) New evidence of the origin of Pre-Cambrian carbon. Bull. Geol. Soc. Am. 59, 389-416.

RANKAMA, K. (1948b) A note on the original isotopic composition of terrestrial carbon J. Geol. 56, 199-209.

RANKAMA, K. (1954) The isotopic constitution of carbon in ancient rocks as an indicator of its biogenic or nonbiogenic origin. Geochim. Cosmochim. Acta 5, 142-152.

ROBINSON, D. (1971) The isotopic constitution of carbon in ancient rocks as an indication of its biogenic of limestones. Contr. Mineral. Petrol. 32, 245-250.

SaCKet, W. M., NAKAPARKsin, S. and Dalrymple, E. (1966) Carbon isotope effects in methane production by thermal cracking. Advances in organic geochemistry, ed. G. D. HOBSON and G. C. SPEers, Pergamon Press, 37-53.

SCHWARCZ, H. P. (1966) Oxygen and carbon isotopic fractionation between coexisting metamorphic calcite and dolomite. J. Geol. 74, 38-48.

ShABO, E. V. and MAMCHUR, G. P. (1973) Isotopic composition of graphite and carbonates from the Zaval'ye deposit. Dokl. Akad. Nauk SSSR, 209, 203-206.

SHEPPARD, S. M. F. and SCHWARCZ, H. P. (1970) Fractionation of carbon and oxygen isotopes and magnesium between coexisting metamorphic calcite and dolomite. Contr. Mineral. Petrol.26, 161198.

SHIEH, Y. N. and TAYLOR, H. P. JR. (1969a) Oxygen and carbon isotope studies of contact metamorphism of carbonate rocks. J. Petrol. 10, 307-331.

SHIEH, Y. N. and TAYLOR, H. P. JR. (1969b) Oxygen and hydrogen isotope studies of contact metamorphism in the Santa Rosa Range, Nevada and other areas. Contr. Mineral. Petrol. 20, 306-356. 
SUWA, K., OSAKI, S., OANA, S., ShiIdA, I. and MiYaGaWA, K. (1969) Isotope geochemistry and petrology of the Mbeya carbonatite, south-western Tanzania, East Africa. J. Earth Sci. Nagoya Univ. 17, 125-168.

SUZUKI, K. (1975) On some unusual bands and veins metasomatically developed in the contact aureole in Kasuga-mura, Gifu-ken. J. Geol. Soc. Jap. 81, 487-504 (in Japanese with English abstract).

WICKMAN, F. E. and UBISCH, H. VON (1951) Two notes on the isotopic constitution of carbon in minerals. Geochim. Cosmochim. Acta 1, 119-122.

WYllie, P. J. and TutTle, O. F. (1960) The system $\mathrm{CaO}-\mathrm{CO}_{2}-\mathrm{H}_{2} \mathrm{O}$ and the origin of carbonatite. $J$. Petrol. 1, 1-46. 